\title{
Two-spotted cricket as an animal infection model of human pathogenic fungi
}

\author{
Yuto Kochi $^{1}$, Yasuhiko Matsumoto ${ }^{2}$, Kazuhisa Sekimizu ${ }^{2}$, Chikara Kaito ${ }^{1, *}$ \\ ${ }^{1}$ Laboratory of Microbiology, Graduate School of Pharmaceutical Sciences, The University of Tokyo, Bunkyo-ku, Tokyo, Japan; \\ ${ }^{2}$ Institute of Medical Mycology, Teikyo University, Tokyo, Japan.
}

\begin{abstract}
Summary Invertebrate infection models that can be evaluated at human body temperature are limited. In this study, we utilized the two-spotted cricket, a heat-tolerant insect, as an animal infection model of human pathogenic fungi. Injection of human pathogenic fungi, including Candida albicans, Candida glabrata, and Cryptococcus neoformans killed crickets within $48 \mathrm{~h}$ at both $27^{\circ} \mathrm{C}$ and $37^{\circ} \mathrm{C}$. The median lethal dose values $\left(\mathrm{LD}_{50}\right.$ values) of $C$. albicans and $C$. glabrata against crickets were decreased at $37^{\circ} \mathrm{C}$ compared to that at $27^{\circ} \mathrm{C}$, whereas the $\mathrm{LD}_{50}$ value of $C$. neoformans was not different between $27^{\circ} \mathrm{C}$ and $37^{\circ} \mathrm{C}$. Heat-killed cells of the three different fungi also killed crickets, but the $\mathbf{L D}_{50}$ value of the heat-killed cells was higher than 5 -fold that of live fungal cells in the respective species. C. neoformans gene-knockout strains of cnal, gpal, and pka1, which are required for virulence in mammals, had greater $\mathbf{L D}_{50}$ values than the parent strain in crickets. These findings suggest that the two-spotted cricket is a valuable infection model of human pathogenic fungi that can be used to evaluate fungal virulence at variable temperatures, including $37^{\circ} \mathrm{C}$, and that the killing abilities of $C$. albicans and $C$. glabrata against animals are increased at $37^{\circ} \mathrm{C}$.
\end{abstract}

Keywords: Cricket, animal infection model, temperature, virulence, human pathogenic fungi

\section{Introduction}

Human pathogenic fungi such as Candida albicans, Candida glabrata, and Cryptococcus neoformans cause superficial infections in the skin and oral cavity as well as deep infections in organs such as the lung and brain. Immunocompromised patients, such as those with AIDS and cancer, are especially susceptible to lethal fungal infection (1-4). Because fungi are eukaryotes, limited numbers of antifungal drugs are available and thus novel antifungal drugs are desired. To develop new antifungal drugs, it is important to understand the molecular mechanisms of fungal infectious processes using an animal infection model and to identify new drug targets. Many mammalian pathogens including fungi are assumed to detect an increase in the environmental

Released online in J-STAGE as advance publication October 29, 2017.

*Address correspondence to:

Dr. Chikara Kaito, Laboratory of Microbiology, Graduate School of Pharmaceutical Sciences, The University of Tokyo, 3-1, 7-chome, Hongo, Bunkyo-ku, Tokyo 113-0033, Japan.

E-mail: kaito@mol.f.u-tokyo.ac.jp temperature as information regarding the host environment $(5)$. At $37^{\circ} \mathrm{C}$, the human body temperature, C. albicans modulates its nucleosome structure with temperature-induced transcription factors to accomplish physiologic alterations that enhance virulence, such as hyphae formation $(6,7)$. To clarify the significance of such temperature-dependent processes for fungal infectious processes, it is essential to utilize animal infection models at both low and high temperatures.

Animal models of infection that can withstand both low and high temperatures, however, are scarce. Mammals such as mice and rabbits have been used to evaluate fungal virulence properties in various organs, including the skin (8), lung (9), stomach (10), oral cavity (11), urethral tube (12), and vagina (13). Mammals are homeothermic animals, however, and cannot be used to evaluate fungal virulence at low temperatures. Many nonmammalian animals have been used as animal models of fungal infection to overcome the ethical and costrelated issues associated with mammalian model animals $(14,15)$; a vertebrate model such as zebra fish (16), and invertebrate models such as nematode (Caenorhabditis elegans) (17), fruit fly (Drosophila melanogaster) (18), silkworm (Bombyx mori) (19,20), and the greater 
wax moth larva (Galleria mellonella) $(21,22)$. The heterothermic characteristics of zebra fish were used to evaluate fungal virulence at a high temperature of $33^{\circ} \mathrm{C}(23,24)$. The applicability of this model at $37^{\circ} \mathrm{C}$, however, is not known. The nematode $C$. elegans and the fruit fly $D$. melanogaster cannot survive at $37^{\circ} \mathrm{C}$. Silkworms and the greater wax moth larva can be used as animal infection models at $37^{\circ} \mathrm{C}(25-27)$, but their infection sensitivities to fungi are drastically increased at $37^{\circ} \mathrm{C}$ compared to that at a lower temperature $(19,28$ 31). The increased infection sensitivity of these insects at $37^{\circ} \mathrm{C}$ is considered to be due to damage to the immune system at a high temperature (32-34).

We focused on the two-spotted cricket, Gryllus bimaculatus, an Orthopteran insect that is distributed across tropical and subtropical regions in the world, to investigate the effects of temperature on the infectious processes of human pathogens. The two-spotted cricket develops from nymph to adult at a wide range of temperatures, from $19^{\circ} \mathrm{C}$ to $37^{\circ} \mathrm{C}(35,36)$. We previously reported that the two-spotted cricket is infected and killed by human pathogenic bacteria, including Staphylococcus aureus, Pseudomonas aeruginosa, and Listeria monocytogenes (37). The infection sensitivity of the two-spotted cricket to $S$. aureus and $P$. aeruginosa does not differ between $27^{\circ} \mathrm{C}$ and $37^{\circ} \mathrm{C}$, but the infection sensitivity to L. monocytogenes is higher at $37^{\circ} \mathrm{C}$ than at $27^{\circ} \mathrm{C}(37)$. Thus, the two-spotted cricket does not generally increase the infection sensitivity to pathogens at $37^{\circ} \mathrm{C}$, and is an animal infection model that can be used to evaluate the effect of temperature on infectious processes without perturbing host system to identify the temperature-dependent virulence mechanisms of specific pathogens. In addition, the twospotted cricket is available at a low price throughout the world, because crickets are cultured as food for amphibians and reptiles. The body size of the cricket is appropriate for injecting accurate amounts of samples and to quantitatively evaluate the virulence properties of pathogens by determining the median lethal dose $\left(\mathrm{LD}_{50}\right)$ value (37). In this study, we examined the virulence properties of human pathogenic fungi, including $C$. albicans, C. glabrata, and $C$. neoformans, using the cricket infection model at $27^{\circ} \mathrm{C}$ and $37^{\circ} \mathrm{C}$. The findings revealed that the two-spotted cricket can be used as an animal infection model of human pathogenic fungi, and that $C$. albicans and C. glabrata exhibit increased killing abilities against crickets at a high temperature.

\section{Materials and Methods}

\subsection{Crickets}

Two-spotted crickets in the final nymph stage were purchased from Tsukiyono Farm (Tone-gun, Gunma, Japan) and raised to adults by feeding them water and food at $27^{\circ} \mathrm{C}$, as previously reported $(38,39)$. Briefly,
Table 1. Fungal strains used in this study

\begin{tabular}{|c|c|c|}
\hline Strain & Genotypes and Characteristics & Ref. \\
\hline \multicolumn{3}{|c|}{ Candida albicans } \\
\hline ATCC10231 & Serotype A & $(56)$ \\
\hline \multicolumn{3}{|c|}{ Candida glabrata } \\
\hline CBS138 & ATCC2001 & $(57)$ \\
\hline \multicolumn{3}{|c|}{ Cryptococcus neoformans } \\
\hline H99 & Serotype A, clinical isolate & $(58)$ \\
\hline$\Delta c n a$ & H99, cna1::ade2, mata & (43) \\
\hline$\Delta g p a l$ & H99, gpa1:: ade2, mata & (45) \\
\hline$\Delta p k a 1$ & $\mathrm{H} 99$, pka1:: ade2, mat $\alpha$ & (47) \\
\hline
\end{tabular}

100 crickets were kept in a plastic cage $(\mathrm{W} 320 \times$ L170 $\times$ H210) with food 'Koorogi-food' (Tsukiyono-Farm), wet paper towel, and paper egg trays. Adult crickets within 1 week after eclosion were used for the infection experiments.

\subsection{Fungal strains and culture conditions}

Fungal strains, including C. albicans, C. glabrata, C. neoformans, and the gene-knockout strains of $C$. neoformans, which were stocked at $-80^{\circ} \mathrm{C}$, were streaked on YPD agar plates and cultured overnight at $30^{\circ} \mathrm{C}$. A single colony of each strain was inoculated into $30 \mathrm{ml}$ of YPD liquid medium in a 225-mL conical tube (cat. no. 352075, BD Falcon, Bedford, MA) and aerobically cultured overnight by shaking at $150 \mathrm{rpm}$ (BR-3000LF, TAITEC co., ltd., Koshigaya, Saitama, Japan) at $30^{\circ} \mathrm{C}$. The details of the fungal strains used in this study are listed in Table 1.

\subsection{Infection experiments using crickets}

Overnight fungal cultures were centrifuged at 5,000 $g$ for $6 \mathrm{~min}$ and the precipitated cells were suspended in saline. The fungal cell solution was serially diluted with saline. Crickets were injected with $50 \mu \mathrm{L}$ of fungal solution via an intra-hemolymph route from the ventral abdominal region using a 1-mL syringe equipped with a 30 gauge-needle, as previously reported (37). The injected crickets ( $n=5$ /group) were maintained in a disposable cylindrical dish $($ \$129 × H97 mm, MINERON KASEI Co., Ltd., Higashi-Osaka, Osaka, Japan) with food and wet Kimwipes (NIPPON PAPER CRECIA Co., Ltd., Chiyoda-ku, Tokyo, Japan) in dark conditions at $27^{\circ} \mathrm{C}$ or $37^{\circ} \mathrm{C}$. Cricket survival was monitored after the injection. The fungal solution used for the infection experiment was $10^{5}$-fold diluted with saline, spread onto YPD agar plates, and incubated overnight at $30^{\circ} \mathrm{C}$. The appearing colonies were counted and the number of live fungal cells injected into the crickets was calculated. The $\mathrm{LD}_{50}$ values of fungal strains against the crickets were determined by logistic regression from the dose-survival plots. All the survival data are listed in Table S1 (http://www.ddtjournal.com/ action/getSupplementalData.php?ID=16). 


\subsection{Preparation of heat-killed fungal cells}

Overnight fungal cultures were centrifuged at 5,000 $\mathrm{g}$ for $6 \mathrm{~min}$, and the precipitated cells were suspended in 1 $\mathrm{mL}$ of saline and transferred to a 2-mL Eppendorf tube. A small part of the fungal solution was $10^{5}$-fold diluted with saline, spread onto YPD agar plates, and incubated overnight at $30^{\circ} \mathrm{C}$ to measure the number of fungal cells. The fungal solution in a 2-mL Eppendorf tube was autoclaved at $121^{\circ} \mathrm{C}$ for $20 \mathrm{~min}$, serially diluted with saline, and used for the infection experiments.

\subsection{Measurement of fungal doubling time}

Single colonies of $C$. albicans, C. glabrata, or $C$. neoformans were inoculated into $10 \mathrm{~mL}$ of YPD liquid medium in a 50-mL conical tube (Cat. No. 352070, BDFalcon) and aerobically cultured overnight at $30^{\circ} \mathrm{C}$ by shaking at $150 \mathrm{rpm}$. A $100-\mu \mathrm{L}$ aliquot of the overnight culture was inoculated into $10 \mathrm{~mL}$ of YPD liquid medium in a $50-\mathrm{mL}$ conical tube and aerobically cultured by shaking at $150 \mathrm{rpm}$ at $27^{\circ} \mathrm{C}$ or $37^{\circ} \mathrm{C}$. The $\mathrm{OD}_{600}$ values were measured over time using a spectrophotometer (UV-1280, SHIMADZU Co., Kyoto, Japan). To measure the condensed cell culture, the culture was appropriately
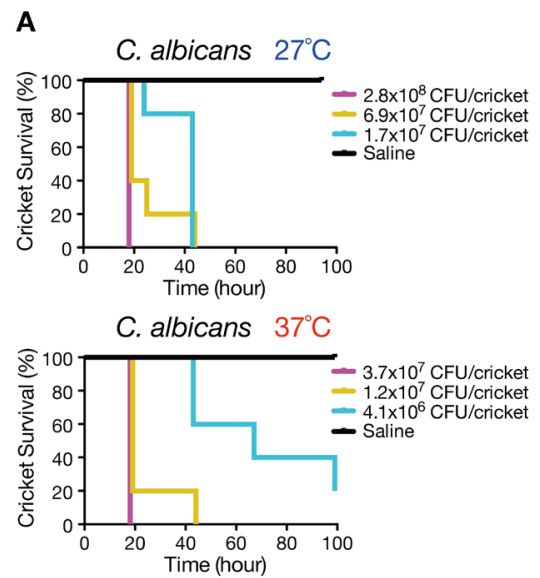

C
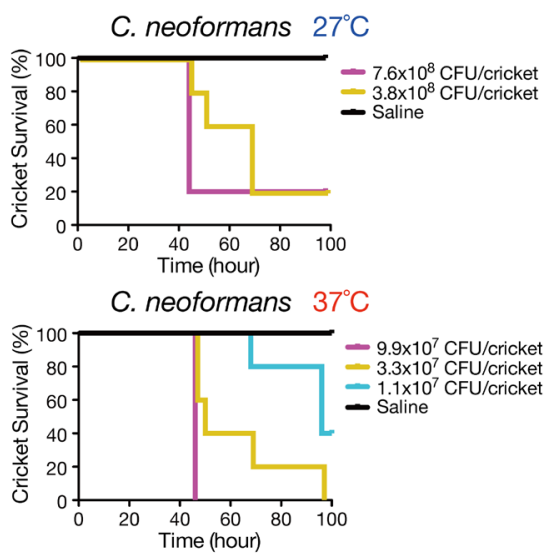

diluted with saline. The doubling time was calculated from the exponential growth phase by linear regression, as previously reported $(40,41)$.

\subsection{Statistical analysis}

Cricket survival at different fungal doses were plotted on an X-Y graph and the dose-response survival curves were determined by logistic regression. To compare the two dose-survival curves, a likelihood ratio test was performed using $\mathrm{R}$ ver. 3.2.3 (42). The $\mathrm{LD}_{50}$ value and the standard error were determined using 'Mass' in $\mathrm{R}$.

\section{Results}

\subsection{Cricket killing by human pathogenic fungi}

To determine whether human pathogenic fungi kill the two-spotted crickets, we injected $C$. albicans, $C$. glabrata, and $C$. neoformans into crickets via the intrahemolymph route and maintained the crickets at $27^{\circ} \mathrm{C}$ or $37^{\circ} \mathrm{C}$. At both temperatures, a high number of C. albicans cells killed crickets within $18 \mathrm{~h}$ after the injection, whereas a low number of $C$. albicans cells killed crickets $40 \mathrm{~h}$ after injection (Figure 1A). A similar tendency was

B
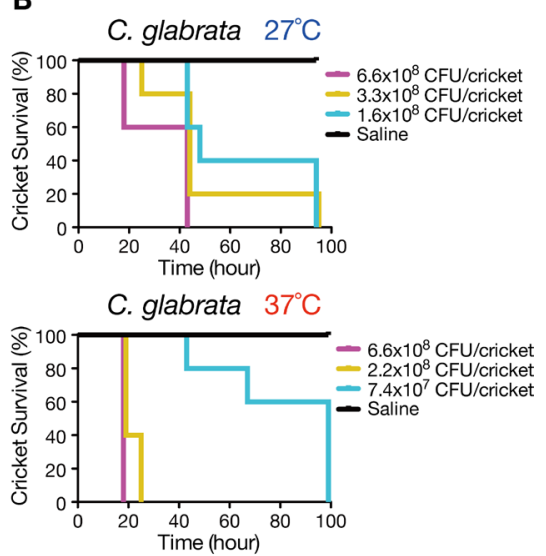

Figure 1. Killing of crickets after injecting human pathogenic fungi. Crickets ( $n=5 /$ group) were injected with saline or various doses of C. albicans (A), C. glabrata (B), or C. neoformans (C), and were maintained at $27^{\circ} \mathrm{C}$ or $37^{\circ} \mathrm{C}$. The time-course of cricket survival was monitored. 

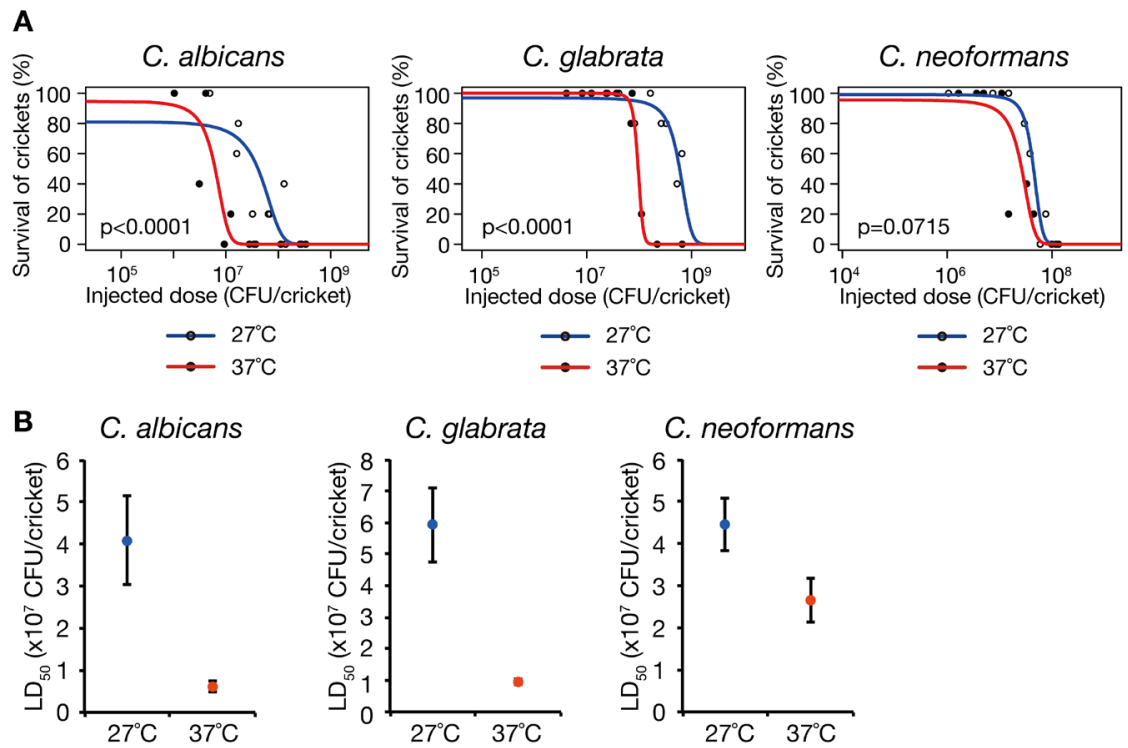

Figure 2. Effect of temperature on cricket sensitivity against fungal infection. (A) The dose-response survival curve of crickets injected with C. albicans, C. glabrata, or C. neoformans was examined at $27^{\circ} \mathrm{C}$ or $37^{\circ} \mathrm{C}$. Serial dilutions of the fungal solution were injected into crickets $(n=5 /$ dose $)$ and survival was monitored at $24 \mathrm{~h}(C$. albicans and C. glabrata) or $48 \mathrm{~h}(C$. neoformans $)$ after the injection. Results from independent experiments $\left(C\right.$. albicans $\left[27^{\circ} \mathrm{C}\right]$, three times; C. albicans $\left[37^{\circ} \mathrm{C}\right]$, two times; C. glabrata $\left[27^{\circ} \mathrm{C}\right]$, three times; $C$. glabrata $\left[37^{\circ} \mathrm{C}\right]$, three times; C. neoformans $\left[27^{\circ} \mathrm{C}\right]$, three times; $C$. neoformans $\left[37^{\circ} \mathrm{C}\right]$, two times) were pooled and the survival curve was determined by logistic regression. The $p$-values determined by using likelihood ratio tests between the survival curves at $27^{\circ} \mathrm{C}$ and $37^{\circ} \mathrm{C}$ are presented in the graphs. All survival data are presented in Table S1 (Supporting Information) and no crickets injected with saline died in any of the experiments. (B) The $\mathrm{LD}_{50}$ values of C. albicans, C. glabrata, or C. neoformans at $27^{\circ} \mathrm{C}$ or $37^{\circ} \mathrm{C}$ were determined by logistic regression in (A). Error bars indicate standard errors.
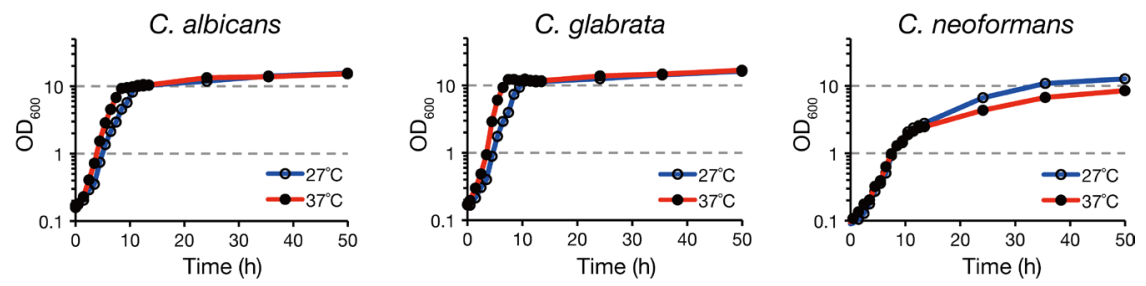

Figure 3. Effect of temperature on fungal growth curve. Overnight cultures of C. albicans, C. glabrata, or C. neoformans were inoculated into 100 -fold amounts of fresh YPD medium and aerobically cultured at $27^{\circ} \mathrm{C}$ or $37^{\circ} \mathrm{C}$. $\mathrm{OD}_{600}$ was measured during the time-course.

observed in the injection of C. glabrata cells (Figure 1B). C. neoformans killed crickets $43 \mathrm{~h}$ after injection (Figure 1C). In all experiments, injection of saline did not kill the crickets (Figures 1A-1C). These results suggest that $C$. albicans, C. glabrata, and C. neoformans kill crickets.

\subsection{Comparison of cricket killing ability by fungi between $27^{\circ} \mathrm{C}$ and $37^{\circ} \mathrm{C}$}

Because the two-spotted cricket does not universally increase infection sensitivity to pathogens (37), the twospotted cricket is useful for evaluating the temperature effect on the infection properties of pathogens. We examined whether $C$. albicans, C. glabrata, and $C$. neoformans increase their killing activities against crickets at a higher temperature. Crickets were injected with fungi, maintained at $27^{\circ} \mathrm{C}$ or $37^{\circ} \mathrm{C}$, and survival was measured. The dose-response survival curve of $C$. albicans differed between $27^{\circ} \mathrm{C}$ and $37^{\circ} \mathrm{C}$ (Figure 2A), and the $\mathrm{LD}_{50}$ value at $37^{\circ} \mathrm{C}$ was less than one-fifth that at $27^{\circ} \mathrm{C}$ (Figure 2B). The dose-response survival curve of $C$. glabrata was different between $27^{\circ} \mathrm{C}$ and $37^{\circ} \mathrm{C}$ (Figure $2 \mathrm{~A}$ ), and the $\mathrm{LD}_{50}$ value at $37^{\circ} \mathrm{C}$ was less than one-fifth that at $27^{\circ} \mathrm{C}$ (Figure 2B). In contrast, the dose-response survival curve of $C$. neoformans did not differ between $27^{\circ} \mathrm{C}$ and $37^{\circ} \mathrm{C}$ (Figure 2A). These results suggest that C. albicans and C. glabrata have increased killing ability against crickets at $37^{\circ} \mathrm{C}$ compared to $27^{\circ} \mathrm{C}$.

\subsection{Comparison of fungal growth between $27^{\circ} \mathrm{C}$ and $37^{\circ} \mathrm{C}$}

We hypothesized that one reason for the increased virulence of $C$. albicans and C. glabrata at a high temperature is an increased growth rate at high temperature. To address this point, we measured the growth curves of $C$. albicans, C. glabrata, and $C$. neoformans at $27^{\circ} \mathrm{C}$ and $37^{\circ} \mathrm{C}$, and determined the doubling times. All fungal strains showed logarithmic growth from $2 \mathrm{~h}$ to $6 \mathrm{~h}$ after inoculation (Figure 3). The 
doubling times of $C$. albicans and C. glabrata were shorter at $37^{\circ} \mathrm{C}$ than at $27^{\circ} \mathrm{C}$ (Table 2). In contrast, the doubling time of $C$. neoformans was not shorter at $37^{\circ} \mathrm{C}$ than at $27^{\circ} \mathrm{C}$ (Table 2). These results suggest that the growth rates of $C$. albicans and C. glabrata increase at $37^{\circ} \mathrm{C}$ compared to at $27^{\circ} \mathrm{C}$.

\subsection{Killing activity of heat-killed fungal cells against crickets}

To address whether the cricket killing ability by fungi is caused by live fungal cells, we examined the killing activities of heat-killed fungal cells against crickets. $C$. albicans, C. glabrata, and C. neoformans cells were autoclaved and injected into crickets. In all fungal species, the dose-response survival curve was different between the live fungal cells and the heat-killed fungal cells (Figure 4A). The $\mathrm{LD}_{50}$ value of heat-killed fungal cells was higher than 5 -fold that of live fungal cells in

Table 2. Doubling times of fungal strains

\begin{tabular}{lccc}
\hline Temperature & C. albicans & C. glabrata & C. neoformans \\
\hline $27^{\circ} \mathrm{C}$ & $1.56 \pm 0.09$ & $1.34 \pm 0.16$ & $1.80 \pm 0.04$ \\
$37^{\circ} \mathrm{C}$ & $1.05 \pm 0.04$ & $0.802 \pm 0.020$ & $2.16 \pm 0.22$ \\
$P$ value & 0.0099 & 0.0259 & 0.0776 \\
\hline
\end{tabular}

Doubling time (h) was calculated from fungal growth curves at $27^{\circ} \mathrm{C}$ or $37^{\circ} \mathrm{C}$. Data are the means \pm standard errors from three independent experiments. Student's $t$-test p values between $27^{\circ} \mathrm{C}$ and $37^{\circ} \mathrm{C}$ are presented. each species (Figure 4B). These results suggest that live fungal cells have higher killing activity against crickets than dead fungal cells.

\subsection{Killing activities of C. neoformans gene-knockout strains against crickets}

To determine the applicability of the cricket model for evaluation of fungal virulence factors, we examined whether the $C$. neoformans gene-knockout strains of cnal, gpal, and pka1, which are virulence factors in mammals, exhibit decreased killing activities against crickets. cnal encodes a subunit of calcineurin, a protein phosphatase involved in the signaling pathway $(43,44)$. gpal and pkal are involved in capsule formation and melanin synthesis via a calcineurin-independent pathway (45-47). Crickets were injected with the gene-knockout strains and the dose-response survival curve at $37^{\circ} \mathrm{C}$ was determined. The survival curve differed between the parent strain and the respective gene-knockout strain (Figure 5A). The $\mathrm{LD}_{50}$ values of the cnal-, gpal-, and pka1-knockout strains were higher than 2-fold that of the parent strains (Figure 5B). These results suggest that the cricket-fungus infection model is effective for evaluating fungal virulence factors.

\section{Discussion}

This study revealed that human pathogenic fungi,
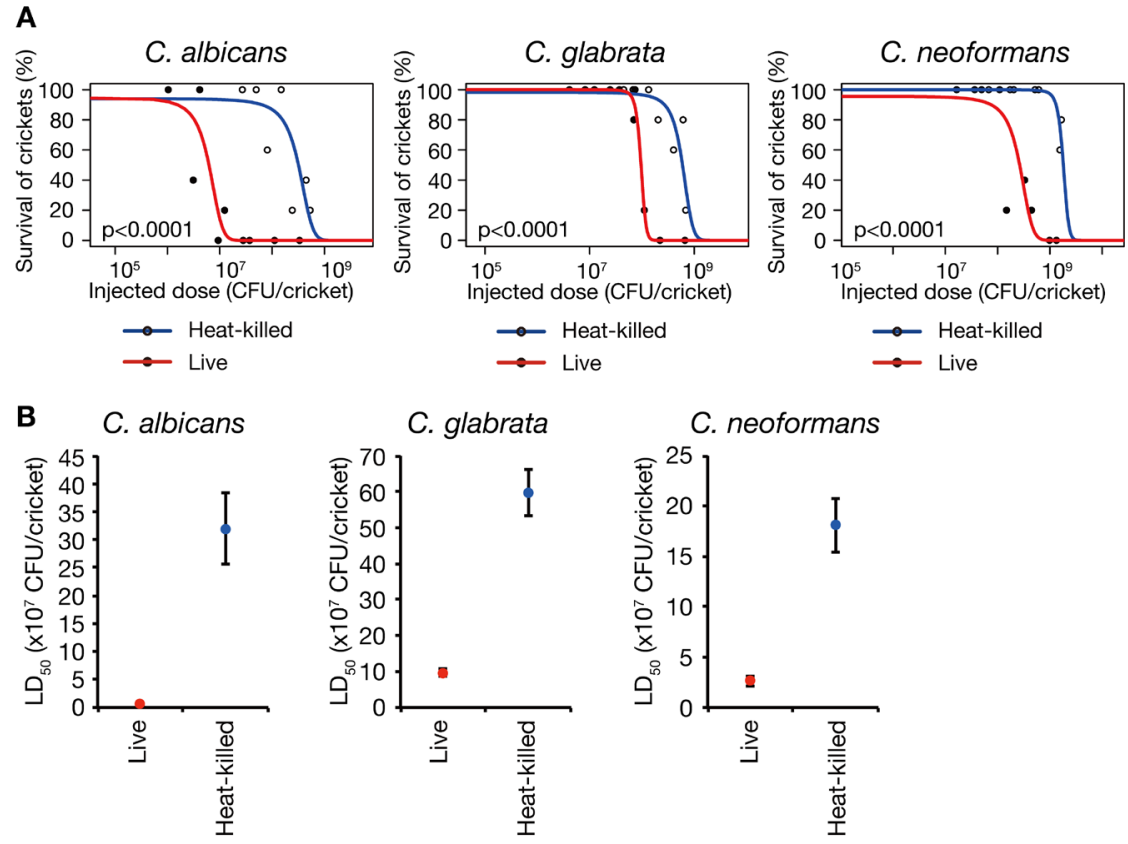

Figure 4. Killing effects of heat-killed fungal cells against crickets. (A) The dose-response survival curve of crickets injected with heat-killed cells of C. albicans, C. glabrata, or C. neoformans was examined at $37^{\circ} \mathrm{C}$. Serial dilutions of heat-killed fungal solutions were injected into crickets $(n=5 /$ dose $)$ and survival was monitored at $24 \mathrm{~h}(C$. albicans and $C$. glabrata $)$ or $48 \mathrm{~h}(C$. neoformans $)$ after the injection. Results from three independent experiments were pooled and the survival curve was determined by logistic regression. Results of live fungal cells (closed symbols and red line) are the same as in Figure 2A. The p-values determined by using likelihood ratio tests between the survival curves of dead fungal cells and of live fungal cells are presented in the graphs. All survival data are presented in Table S1 (Supporting Information), and no crickets injected with saline died in any of the experiments. (B) The $\mathrm{LD}_{50}$ values of heat-killed fungal cells were determined by logistic regression in (A). The $\mathrm{LD}_{50}$ values of live fungal cells were the same as those in Figure 2B. Error bars indicate standard errors. 

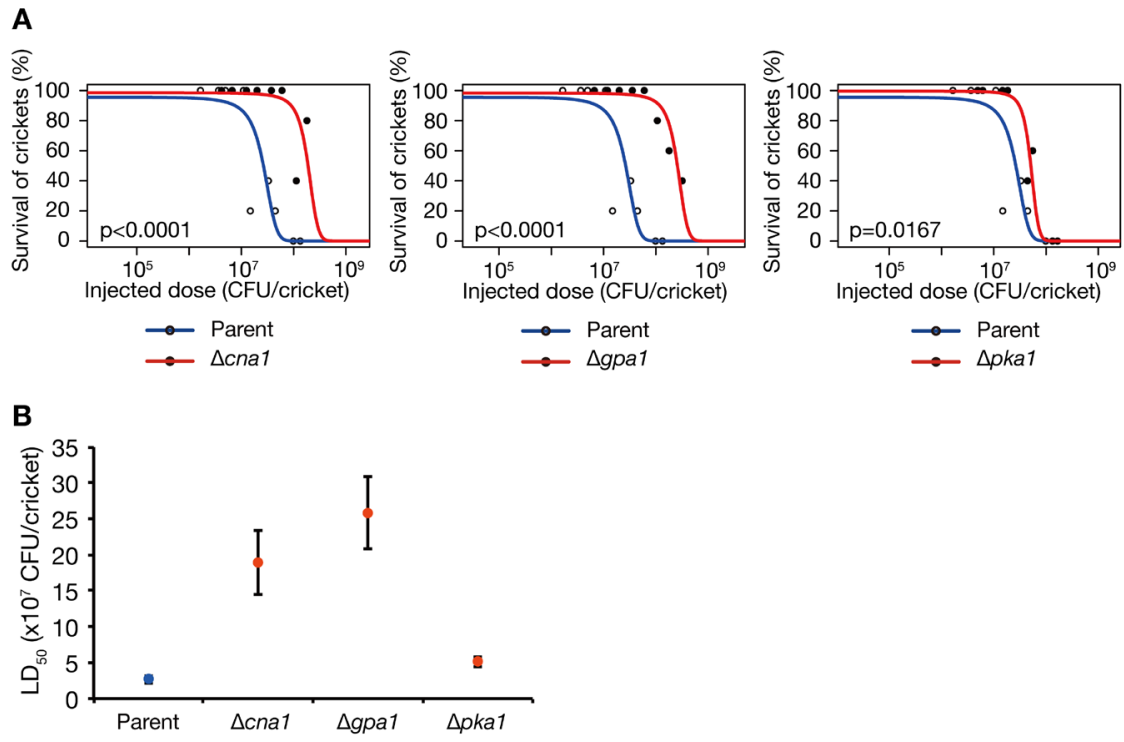

Figure 5. Evaluation of $\boldsymbol{C}$. neoformans virulence factors in the cricket infection model. (A) The dose-response survival curves of crickets $(n=5 /$ dose $)$ injected with $C$. neoformans gene knockout strains of cnal, gpal, and pkal were determined at $37^{\circ} \mathrm{C}$. Survival was monitored at $48 \mathrm{~h}$ after fungal injection. Results from two independent experiments were pooled and the survival curve was determined by logistic regression. All survival data are presented in Table S1 (Supporting Information) and no crickets injected with saline died in any of the experiments. The $p$-values determined using likelihood ratio tests between the parent strain and the geneknockout strain are presented in the graphs. The survival curve of crickets infected with the parent strain of $C$. neoformans was the same as in Figure $2 \mathrm{~A}\left(\right.$ C. neoformans, $\left.37^{\circ} \mathrm{C}\right)$. (B) The $\mathrm{LD}_{50}$ values of $C$. neoformans gene knockout strains of cnal, gpal, and pka1 were determined by logistic regression in (A) and compared with the parent strain. The $\mathrm{LD}_{50}$ value of the parent strain was the same as that in Figure $2 \mathrm{~B}\left(\mathrm{C}\right.$. neoformans, $\left.37^{\circ} \mathrm{C}\right)$. Error bars indicate standard errors.

including C. albicans, C. glabrata, and C. neoformans, kill the two-spotted cricket. The killing activity of the fungi was drastically decreased by heat inactivation of the fungal cells, indicating that live fungal cells contribute to kill crickets. Furthermore, we evaluated fungal virulence against crickets at both $27^{\circ} \mathrm{C}$ and $37^{\circ} \mathrm{C}$, and revealed that the killing activities of $C$. albicans and C. glabrata were increased at $37^{\circ} \mathrm{C}$ compared to that at $27^{\circ} \mathrm{C}$, but the killing activity of C. neoformans was not different between the two temperatures. This study also demonstrated that the $C$. neoformans gene-knockout strains of virulence factors attenuated the killing activities against crickets. Based on these results, we propose that the two-spotted cricket is a useful animal infection model of human pathogenic fungi, and is effective for clarifying the temperature-dependent virulence system of fungal pathogens.

To our knowledge, this study is the first to reveal that C. albicans and C. glabrata exhibit a temperaturedependent increase in killing activity against animals. This finding was obtained because we utilized the twospotted cricket, a heterothermic animal, which can grow at both $27^{\circ} \mathrm{C}$ and $37^{\circ} \mathrm{C}$. We found that the growth rate of these two fungi increases at $37^{\circ} \mathrm{C}$, compared to that at $27^{\circ} \mathrm{C}$, and assumed it to be a possible reason for the increased killing activities at $37^{\circ} \mathrm{C}$. In addition to the growth rate, increasing the temperature leads to many physiologic alterations of fungi. C. albicans forms hyphae at high temperature, and a gene-knockout strain that is unable to form hyphae exhibits attenuated virulence
$(48,49)$. C. glabrata alters cell surface polysaccharides and shows different cell surface hydrophobicity at $37^{\circ} \mathrm{C}$ compared to that at a lower temperature $(50,51)$. C. neoformans upregulates nucleotide metabolism and capsule formation at a high temperature, enabling growth at a high temperature $(52,53)$. Because $C$. neoformans did not exhibit increased killing activity against crickets at $37^{\circ} \mathrm{C}$, the physiologic alteration that is present in the two Candida species but is absent in C. neoformans may contribute to the temperature-dependent killing activity against crickets. These points should be investigated in future studies by evaluating the virulence properties of fungal genetic mutants for each physiologic process in the cricket infection model to clarify the temperaturedependent virulence system of these fungi.

Heat-killed fungal cells showed killing activity against crickets, although the killing activity of the heat-killed fungal cells was drastically lower than that of live fungal cells. It is plausible that live fungal cells proliferate in the cricket body and the proliferated fungal cells kill crickets in the same manner as the heatkilled cells. In silkworms, $\beta$-glucan, a component of the fungal cell wall, excessively activates the humoral immune system, which kills silkworms $(54,55)$. To optimize the utility of the two-spotted cricket as an animal infection model of human pathogenic fungi, further studies are needed to investigate the immune response of crickets against fungal cells and to reveal the molecular mechanism underlying infection-induced death in crickets. 


\section{Acknowledgements}

This work was supported by Grants-in-Aid for Scientific Research [grant number 16K15274].

\section{References}

1. Cassone A, Cauda R. Candida and candidiasis in HIVinfected patients: Where commensalism, opportunistic behavior and frank pathogenicity lose their borders. AIDS. 2012; 26:1457-1472.

2. Silva S, Negri M, Henriques M, Oliveira R, Williams DW, Azeredo J. Candida glabrata, Candida parapsilosis and Candida tropicalis: Biology, epidemiology, pathogenicity and antifungal resistance. FEMS Microbiol Rev. 2012; 36:288-305.

3. Ramirez-Garcia A, Rementeria A, Aguirre-Urizar JM, Moragues MD, Antoran A, Pellon A, Abad-Diaz-de-Cerio A, Hernando FL. Candida albicans and cancer: Can this yeast induce cancer development or progression? Crit Rev Microbiol. 2016; 42:181-193.

4. Wingard JR. Infections due to resistant Candida species in patients with cancer who are receiving chemotherapy. Clin Infect Dis. 1994; 19 (Suppl 1):S49-53.

5. Shapiro RS, Cowen LE. Thermal control of microbial development and virulence: Molecular mechanisms of microbial temperature sensing. MBio. 2012; 3. pii: e00238-12.

6. Leach MD, Farrer RA, Tan K, Miao Z, Walker LA, Cuomo CA, Wheeler RT, Brown AJ, Wong KH, Cowen LE. Hsf1 and Hsp90 orchestrate temperature-dependent global transcriptional remodelling and chromatin architecture in Candida albicans. Nat Commun. 2016; 7:11704.

7. Shapiro RS, Uppuluri P, Zaas AK, Collins C, Senn H, Perfect JR, Heitman J, Cowen LE. Hsp90 orchestrates temperature-dependent Candida albicans morphogenesis via Ras1-PKA signaling. Curr Biol. 2009; 19:621-629.

8. De Cremer K, Delattin N, De Brucker K, Peeters A, Kucharikova S, Gerits E, Verstraeten N, Michiels J, Van Dijck P, Cammue BP, Thevissen K. Oral administration of the broad-spectrum antibiofilm compound toremifene inhibits Candida albicans and Staphylococcus aureus biofilm formation in vivo. Antimicrob Agents Chemother. 2014; 58:7606-7610.

9. Murdock BJ, Teitz-Tennenbaum S, Chen GH, Dils AJ, Malachowski AN, Curtis JL, Olszewski MA, Osterholzer JJ. Early or late IL-10 blockade enhances Th1 and Th17 effector responses and promotes fungal clearance in mice with cryptococcal lung infection. J Immunol. 2014; 193:4107-4116.

10. Maekawa T, Ishijima AS, Ida M, Izumo T, Ono Y, Shibata H, Abe S. Prophylactic effect of Lactobacillus pentosus strain S-PT84 on Candida infection and gastric inflammation in a murine gastrointestinal candidiasis model. Med Mycol J. 2016; 57:E81-E92.

11. Altmeier S, Toska A, Sparber F, Teijeira A, Halin C, LeibundGut-Landmann S. IL-1 coordinates the neutrophil response to C. albicans in the oral mucosa. PLoS Pathog. 2016; 12:e1005882.

12. Stock SJ, Patey O, Thilaganathan B, White S, Furfaro LL, Payne MS, Spiller OB, Noe A, Watts R, Carter $\mathrm{S}$, Ireland DJ, Jobe AH, Newnham JP, Kemp MW. Intrauterine Candida albicans infection causes systemic fetal candidiasis with progressive cardiac dysfunction in a sheep model of early pregnancy. Reprod Sci. 2016. pii: 1933719116649697.

13. Nash EE, Peters BM, Lilly EA, Noverr MC, Fidel PL, Jr. A murine model of Candida glabrata vaginitis shows no evidence of an inflammatory immunopathogenic response. PLoS One. 2016; $11: \mathrm{e} 0147969$.

14. Baumans V. Use of animals in experimental research: An ethical dilemma? Gene Ther. 2004; 11 (Suppl 1):S64-66.

15. Kaito C, Yoshikai H, Sekimizu K. Utilization of a silkworm model for understanding host-pathogen interactions. Invert Surviv J. 2012; 9:163-168.

16. Tenor JL, Oehlers SH, Yang JL, Tobin DM, Perfect JR. Live Imaging of host-parasite interactions in a zebrafish infection model reveals cryptococcal determinants of virulence and central nervous system invasion. MBio. 2015; 6:e01425-01415.

17. Mylonakis E, Ausubel FM, Perfect JR, Heitman J, Calderwood SB. Killing of Caenorhabditis elegans by Cryptococcus neoformans as a model of yeast pathogenesis. Proc Natl Acad Sci U S A. 2002; 99:1567515680 .

18. Glittenberg MT, Silas S, MacCallum DM, Gow NA, Ligoxygakis P. Wild-type Drosophila melanogaster as an alternative model system for investigating the pathogenicity of Candida albicans. Dis Model Mech. 2011; 4:504-514.

19. Matsumoto Y, Miyazaki S, Fukunaga DH, Shimizu K, Kawamoto S, Sekimizu K. Quantitative evaluation of cryptococcal pathogenesis and antifungal drugs using a silkworm infection model with Cryptococcus neoformans. J Appl Microbiol. 2012; 112:138-146.

20. Hamamoto H, Kurokawa K, Kaito C, Kamura K, Manitra Razanajatovo I, Kusuhara H, Santa T, Sekimizu K. Quantitative evaluation of the therapeutic effects of antibiotics using silkworms infected with human pathogenic microorganisms. Antimicrob Agents Chemother. 2004; 48:774-779.

21. Trevijano-Contador N, Herrero-Fernandez I, GarciaBarbazan I, Scorzoni L, Rueda C, Rossi SA, GarciaRodas R, Zaragoza O. Cryptococcus neoformans induces antimicrobial responses and behaves as a facultative intracellular pathogen in the non mammalian model Galleria mellonella. Virulence. 2015; 6:66-74.

22. Frenkel M, Mandelblat M, Alastruey-Izquierdo A, Mendlovic S, Semis R, Segal E. Pathogenicity of Candida albicans isolates from bloodstream and mucosal candidiasis assessed in mice and Galleria mellonella. J Mycol Med. 2016; 26:1-8.

23. Brudal E, Ulanova LS, E OL, Rishovd AL, Griffiths G, Winther-Larsen HC. Establishment of three Francisella infections in zebrafish embryos at different temperatures. Infect Immun. 2014; 82:2180-2194.

24. Mallick EM, Bergeron AC, Jones SK, Jr., Newman ZR, Brothers KM, Creton R, Wheeler RT, Bennett RJ. Phenotypic plasticity regulates Candida albicans interactions and virulence in the vertebrate host. Front Microbiol. 2016; 7:780.

25. Miyashita A, Iyoda S, Ishii K, Hamamoto H, Sekimizu $\mathrm{K}$, Kaito C. Lipopolysaccharide O-antigen of enterohemorrhagic Escherichia coli O157:H7 is required for killing both insects and mammals. FEMS Microbiol Lett. 2012; 333:59-68.

26. Kaito C, Usui K, Kyuma T, Sekimizu K. Isolation of mammalian pathogenic bacteria using silkworms. Drug 
Discov Ther. 2011; 5:66-70.

27. Thomaz L, Garcia-Rodas R, Guimaraes AJ, Taborda $\mathrm{CP}$, Zaragoza O, Nosanchuk JD. Galleria mellonella as a model host to study Paracoccidioides lutzii and Histoplasma capsulatum. Virulence. 2013; 4:139-146.

28. Garcia-Solache MA, Izquierdo-Garcia D, Smith C, Bergman A, Casadevall A. Fungal virulence in a lepidopteran model is an emergent property with deterministic features. MBio. 2013; 4:e00100-00113.

29. Mylonakis E, Moreno R, El Khoury JB, Idnurm A, Heitman J, Calderwood SB, Ausubel FM, Diener A. Galleria mellonella as a model system to study Cryptococcus neoformans pathogenesis. Infect Immun. 2005; 73:3842-3850.

30. Desbois AP, Coote PJ. Wax moth larva (Galleria mellonella): An in vivo model for assessing the efficacy of antistaphylococcal agents. J Antimicrob Chemother. 2011; 66:1785-1790.

31. Peleg AY, Jara S, Monga D, Eliopoulos GM, Moellering RC, Jr., Mylonakis E. Galleria mellonella as a model system to study Acinetobacter baumannii pathogenesis and therapeutics. Antimicrob Agents Chemother. 2009; 53:2605-2609.

32. Kiuchi T, Aoki F, Nagata M. Effects of high temperature on the hemocyte cell cycle in silkworm larvae. J Insect Physiol. 2008; 54:454-461.

33. Eguchi D, Iwabuchi K. A new cell line from the wax moth Galleria mellonella Linne (Lepidoptera: Pyralididae). In Vitro Cell Dev Biol Anim. 2006; 42:1-3.

34. Browne N, Surlis C, Kavanagh K. Thermal and physical stresses induce a short-term immune priming effect in Galleria mellonella larvae. J Insect Physiol. 2014; 63:2126.

35. Rivnay E, Ziv M. A contribution to the biology of Gryllus bimaculatus Deg. in Israel. Bull Entomol Res. 1963; 54:37-47.

36. Merkel G. The effects of temperature and food quality on the larval development of Gryllus bimaculatus (Orthoptera, Gryllidae). Oecologia. 1977; 30:129-140.

37. Kochi Y, Miyashita A, Tsuchiya K, Mitsuyama M, Sekimizu K, Kaito C. A human pathogenic bacterial infection model using the two-spotted cricket, Gryllus bimaculatus. FEMS Microbiol Lett. 2016; 363. pii: fnw163.

38. Miyashita A, Kizaki H, Sekimizu K, Kaito C. Bodyenlarging effect of royal jelly in a non-holometabolous insect species, Gryllus bimaculatus. Biol Open. 2016; 5:770-776.

39. Miyashita A, Kizaki H, Sekimizu K, Kaito C. No effect of body size on the frequency of calling and courtship song in the two-spotted cricket, Gryllus bimaculatus. PLoS One. 2016; 11:e0146999.

40. Kyuma T, Kizaki H, Ryuno H, Sekimizu K, Kaito C. 16S rRNA methyltransferase KsgA contributes to oxidative stress resistance and virulence in Staphylococcus aureus. Biochimie. 2015; 119:166-174.

41. Kyuma T, Kimura S, Hanada Y, Suzuki T, Sekimizu K, Kaito C. Ribosomal RNA methyltransferases contribute to Staphylococcus aureus virulence. FEBS J. 2015; 282:2570-2584.

42. Team RDC R: A language and environment for statistical computing. R Foundation for Statistical Computing. 2011.

43. Odom A, Muir S, Lim E, Toffaletti DL, Perfect J, Heitman J. Calcineurin is required for virulence of Cryptococcus neoformans. EMBO J. 1997; 16:2576-2589.

44. Steinbach WJ, Reedy JL, Cramer RA, Jr., Perfect JR, Heitman J. Harnessing calcineurin as a novel antiinfective agent against invasive fungal infections. Nat Rev Microbiol. 2007; 5:418-430.

45. Alspaugh JA, Perfect JR, Heitman J. Cryptococcus neoformans mating and virulence are regulated by the G-protein alpha subunit GPA1 and cAMP. Genes Dev. 1997; 11:3206-3217.

46. Kozubowski L, Lee SC, Heitman J. Signalling pathways in the pathogenesis of Cryptococcus. Cell Microbiol. 2009; 11:370-380.

47. D'Souza CA, Alspaugh JA, Yue C, Harashima T, Cox GM, Perfect JR, Heitman J. Cyclic AMP-dependent protein kinase controls virulence of the fungal pathogen Cryptococcus neoformans. Mol Cell Biol. 2001; 21:31793191.

48. Shapiro RS, Cowen L. Coupling temperature sensing and development: Hsp90 regulates morphogenetic signalling in Candida albicans. Virulence. 2010; 1:45-48.

49. Hwang CS, Oh JH, Huh WK, Yim HS, Kang SO. Ssn6, an important factor of morphological conversion and virulence in Candida albicans. Mol Microbiol. 2003; 47:1029-1043.

50. Okawa Y, Goto K. Disappearance of antigenic factor 6 in Candida glabrata IFO 0622 strain cells cultured at high temperature. Biol Pharm Bull. 2006; 29:187-189.

51. Luo G, Samaranayake LP. Candida glabrata, an emerging fungal pathogen, exhibits superior relative cell surface hydrophobicity and adhesion to denture acrylic surfaces compared with Candida albicans. APMIS. 2002; 110:601610.

52. de Gontijo FA, Pascon RC, Fernandes L, Machado J, Jr., Alspaugh JA, Vallim MA. The role of the de novo pyrimidine biosynthetic pathway in Cryptococcus neoformans high temperature growth and virulence. Fungal Genet Biol. 2014; 70:12-23.

53. Yang DH, Jung KW, Bang S, Lee JW, Song MH, FloydAverette A, Festa RA, Ianiri G, Idnurm A, Thiele DJ, Heitman J, Bahn YS. Rewiring of signaling networks modulating thermotolerance in the human pathogen Cryptococcus neoformans. Genetics. 2017; 205:201-219.

54. Ishii K, Hamamoto H, Kamimura M, Sekimizu K. Activation of the silkworm cytokine by bacterial and fungal cell wall components via a reactive oxygen speciestriggered mechanism. J Biol Chem. 2008; 283:2185-2191.

55. Ishii K, Hamamoto H, Imamura K, Adachi T, Shoji M, Nakayama K, Sekimizu K. Porphyromonas gingivalis peptidoglycans induce excessive activation of the innate immune system in silkworm larvae. J Biol Chem. 2010; 285:33338-33347.

56. Lingappa BT, Prasad M, Lingappa Y, Hunt DF, Biemann K. Phenethyl alcohol and tryptophol: Autoantibiotics produced by the fungus Candida albicans. Science. 1969; 163:192-194.

57. Dujon B. Yeasts illustrate the molecular mechanisms of eukaryotic genome evolution. Trends Genet. 2006; 22:375-387.

58. Toffaletti DL, Rude TH, Johnston SA, Durack DT, Perfect JR. Gene transfer in Cryptococcus neoformans by use of biolistic delivery of DNA. J Bacteriol. 1993; 175:14051411 .

(Received October 5, 2017; Revised October 16, 2017; Accepted October 21, 2017) 